\title{
Internalization of the Value of Religious Characters on Students in Civic Education Learning in SMP Negeri 2 Manado
}

\author{
Julien Biringan ${ }^{1, *}$, Rylien Felicia Limeranto ${ }^{2}$, Maxi Ventje Keintjem ${ }^{3}$ \\ ${ }^{1,3}$ Universitas Pendidikan Indonesia, Bandung, Indonesia \\ ${ }^{2}$ Universitas Negeri Surakarta, Surakrta, Indonesia \\ ${ }^{*}$ Corresponding author.Email: julienbiringan@unima.ac.id
}

\begin{abstract}
This study aims to describe the internalization of the value of religious characters on students in the Civic Education learning activities in SMP Negeri 2 Manado. The approach used was qualitative in the descriptive data, and the study was focused on the process of internalizing the value of religious characters that can change students' attitudes and behavior and make them have noble characters. Data collection is done through observation, interviews, and literature study. The research process and data collection were based on the following research indicators: 1) internalization of changing the behavior; 2) internalization of noble character; 3) internalization of service attitudes, 4) internalization of being able to prove; 5) internalization of being able to solve problems; and 6) religious values including receiving or acceptance, responding, valuing or rewarding, organization and characterization. The results of this study showed that Civic Education teachers in internalizing religious values on students showed some of the following: there were changes in attitudes and behavior in believing in religious teachings and doing what was taught in the school environment, praying before and after class, giving advice, and requiring the students to help each other sincerely and faithfully, both to their fellows and particularly to God as the proprietor of life, and if the students found a problem, they would discuss it with the teacher to find a solution.
\end{abstract}

Keywords: character, internalization, learning, religious, values.

\section{INTRODUCTION}

Religious character is an appreciation of religious tenets that one adheres to and has attached to him that raises attitudes or behavior in everyday life, both in attitudes and actions that can distinguish it from the character of others. The character value can be formed by internalizing it into the character education process in every subject taught by all educational institutions. Character education in a system of values inculcation to students in schools includes knowledge, awareness, and willingness components. The value of the national character must be a concern, as there are eighteen values of national character education, and one of them is religious character. The religious character is one of the religious values, as attitude and devout behavior in performing the teachings of the religion embraced, tolerant of the prayer of other religions, and lives in harmony with the other religious adherents.

Furthermore, character is the root of all actions, both good and bad actions [1]. Strong character is a foundation for the human race to live together in peace and safe, free from immoral acts. This religious character is highly needed for students to face the changing times with existing moral degradation. In this case, to be expected can behave by good and bad measures based on religious provisions and commands. Therefore, efforts are needed to improve the quality of education by internalizing character values for students in the education process at schools.

Efforts to improve the quality of educational institutions are in line with positive global competition in education and build the character of students and the need for continuous efforts to achieve goals. Achieving educational goals requires an interaction process implemented in a learning environment of schools and the surrounding environment. Moreover, that for Indonesia, to make the smart and have moral required mental effort revolution integrated with comprehensive character education [2]. It starts from the negative things that often occur due to the influence of social conditions such as violence and juvenile, regarding terms used in character education that has only emerged in the United States in the last decade, including those used in Indonesia in the past two years. Character education, as a deliberate approach by which school personnel, often in conjunction with parents and community members, help children and youth become caring, principled. 
With regards to the studies above, Law of The Republic of Indonesia Number 20 of 2003 on the National Education System, article 3 stated that the National Education functions to develop the capability, character, and civilization of the nation for enhancing its intellectual capacity, and is aimed at developing learners' potentials so that they become persons imbued with human values, who are faithful and pious to one and only God; who possess morals and noble character; who are healthy, knowledgeable, competent, creative, independent; and as citizens, are democratic and responsible. Efforts to develop student potential certainly need to be done by internalizing various character values through a formal education process in schools. It means that the implementation of these character values can be carried out both in the learning process in the classroom or outside the class that takes place in the school environment.

It is in line that class-based character education is integrated into all subjects, whether intended to have nurturant and instructional effects or nurturant effect only [3]. Furthermore, it is said that learning activity outside the classroom is designed for the co-curricular program to each subject, as an effort to habituate good character. What is expected of character-based learning is how teachers can internalize the values in learning activities. Moreover, Civic Education has an educational value, so it must consider the development of values, morals, attitudes, and behavior of students. Therefore, Civic Education learning can be said to be an Affective Teaching must be achieved in the learning process, including the teacher being able to internalize the values of religious characters [4].

There are many internalizations of character values, and one of them is national character education, which is religious character. As stated in the explanation of the 1945 Constitution of the Republic of Indonesia, the proper attitude and behavior in implementing the teachings of the religion embraced, the tolerance for other religious adherents to do the prayer, and living in harmony with others.

Based on the above studies, and by observing various occurred phenomena following the pre-survey results, the religious character building on students at SMP Negeri 2 Manado has not implemented optimally since several students did not care about suggestions and instruction to perform worship. Even when they did it, their attitudes were fading away as some factors influenced it. The influence of globalization made some students focused more on cellphones and others during the worship, some were chatting, and some skipped the worship or did not want to join it. In addition, based on the observation, SMP Negeri 2 Manado has long been located in a heterogeneous area of religious life environment through a way of living of tolerance by upholding mutual respect among the existing religions. Therefore, performing the worship shows harmony because each religious adherent maintains and upholds the values of tolerance, which shows the existence of exemplary religious values.

Furthermore, for Civic Education teachers who carry out the task of building the religious character values of their students, the process of internalizing religious values is carried out in schools through teaching and learning activities in class and outside the classroom by encouraging and obliging them to worship at home. But in practice, some students deviate, which means that there is no willingness to learn in Civic Education subjects and do not want to carry out the instruction of the Civics Education teacher as intended above. It results in these students in bad associations, such as doing brawls, do not go home on time, et cetera.

But on the other hand, it shows that the students' attitude of tolerance was fading away towards the practice of other religions, such as ignorance, selfishness, and et cetera, in terms of building religious values for students of SMP Negeri 2 Manado. So that Civics Education teachers face problems, even are overwhelmed in providing material or teaching students with such behaviors on having a tolerant attitude and good behavior. Therefore, for Civics teachers to minimize the various phenomena and problems that occurred is by expecting the family, in this case, the parents, to show their participation. Because parents must play a role in fostering, educating, and even directing students in good behavior, and there is tolerance between one religion and another so that these students do not easily be engaged in promiscuity. Moreover, parents certainly need to teach the students, who are also their children, to behave and act well.

The strategies taken to minimize the obstacles that appeared are including cooperating with parents and the surrounding community, encouraging parents to pay more attention to their children, and giving students an understanding of the importance of religious character values. That the strategy to internalize the religious character values is to minimize the obstacles that appeared, including cooperating with parents and the surrounding community, encouraging parents to pay more attention to their children, and making students understand the importance of religious character values [5]. In addition to the primary duty of Civic Education teachers to optimize the students' learning, it is also a means to internalize the religious character values of students without neglecting the affective aspects. It means that in addition to building students' knowledge that emphasizes cognitive and psychomotor aspects, teachers are also expected not to ignore the affective in internalizing religious values during teaching and learning activities and student activities outside the classroom.

\section{METHODS}

This research is a descriptive study aimed to present various phenomena that occurred in the research site of SMP Negeri 2 Manado. It was a procedure of 
solving the investigated problem, which was the internalization of religious character values by describing the condition of the research subjects: Civic Education teachers and students at SMP Negeri 2 Manado. There were four people as the source of data in this study, which consisted of the school principal and Civic Education teachers. Data collection was through school visits observation, interviews, and discussions. The data collected was in the form of school information data, data from observations, interviews, and documents. The validity of the data was applied to ensure credibility, transferability, dependability, and confirmability. Data analysis techniques used were transcripts of interview results, data reduction, analysis, data interpretation, and triangulation, and after the data analyzed, the researchers drew a conclusion.

\section{RESULT AND DISCUSSION}

The results of the study showed that through observations and interviews with Civic Education subject teachers and several students at SMP Negeri 2 Manado on the internalization of religious character values in Civics Education learning, of the internalization indicator and indicator of religious values investigated, indicated the following matters: First, the internalization indicator discussed, is as a process of inculcation of value into one's soul so that it is reflecting in the attitudes and behaviors that are showing in everyday life (merged with a person). Internalization as an arrangement of an individual behavior made into thoughts or personality for his actions to be practiced by others. The internalization of religious character values at SMP Negeri 2 Manado was in the Civic Education learning process. However, it was not too comprehensive, an informant said, as it was the domain of Religion Education subject. Second, the indicator of the religious character's values can be referred to as the religion in the existence of divine nature of beliefs above humans, while religious means the religious characteristics found in a person. Data from the research field results found that Civic Education teachers internalized the values of religious characters in the learning process by teaching and requiring students to respect the beliefs and religions of others. In the school environment, attitudes towards religious teachings and command seemed to have changed. However, there was also a lack of religious character values for students at SMP Negeri 2 Manado because of no strict sanctions for students who did not perform the worship at school, and Civics Education teachers did not provide input for students to do the worship outside of school. Third, the internalization indicator of noble character, it was found that internalization for students to have a noble attitude orientation was carried out by Civics teachers in SMP Negeri 2 Manado during the class learning and also when they reprimanded students outside the class.

The teacher tries to internalize the values of religious character by motivating, instructing, and advising students to be obedient to worship at school, at home, and in the community. It turns out that the teacher strives for students of SMP Negeri 2 Manado in all their personalities to have noble character by carrying out instructions and staying away from restrictions as stated in the religious teachings. All students followed several religious tenets. So, the teacher gave advice and obliged them, to not only worship obediently but also practicing it in daily life.

Fourth, indicators of internalizing service attitudes, it was found that Civic Education teachers internalized the value of the character of service attitudes in teaching activity in class. Although sometimes they also encountered numerous obstacles, most of the students wanted to do it, and only a few of them did not want to. However, based on data the writers obtained, they, as Civic Education teachers, tries to instruct the students continuously for them to be able to carry out a way of life to serve sincerely and faithfully, both to their fellows and above all to God as the proprietor of life. Fifth, internalizing the value of the ability to prove and solve problems. It was found that the students at SMP Negeri 2 Manado were able to solve problems as a part of the thinking process, often considered as the most complex process in terms of intelligence functions. The teacher teaches students how to solve the problem by letting them understand that the problem they are facing is a planning process that needs to execute. There is no problem without a solution. The teacher taught them that if they met various problems, they could solve them rightly. The students also agreed to this point, so that the Civic Education teacher found that when students met problems, they openly asked for solutions from the teachers. Sixth, religious value indicator, it was found five sub-indicators, as follows: Reserving or Acceptance, which turned out that students committed to practicing the way of life to respect each other between diverse religious adherents, then the Civic Education teachers taught them to have an attitude of willingness to acknowledge mutual respect with diverse religious adherents; Responding, it was found that the students at SMP Negeri 2 Manado showed a giving response attitude through a positive response to the teaching of Civics Education teachers. However, there were also some students who did not show this kind of attitude. The teaching of Civic Education teacher is for students must have the obedience of worship and an attitude of mutual respect with fellow adherents of different religions both at school and in the neighborhood; Valuing, when the students at SMP Negeri 2 Manado showed an attitude of respect for the teaching delivered by the teacher by realizing that the value of religious character, in terms of obedience and beliefs, must be imbued with their personality. After class, the students continued to have discussions with the teacher regarding the lesson taught, so it can be said that as an attitude of respect for what the teacher taught them. However, a few students were not serious with no statement of serious attitudes to accept and appreciate the teachings of religious norms carried out by Civic Education teachers in the classroom. So they are categorized as students who do not have conscious and obedient attitudes and personality to the religious 
teachings they believe and embrace; Organization, it was found that their attitude to prefer obedience to religious teachings as a value of religious character and commitment, indicated by their statements to teachers who teach them Civics Education that they have the willingness to realize it in real lives. The students stated that they preferred to learn with the teacher and did not want to do various life attitudes of not following religious teachings. It is an attitude statement that to do a good thing, according to religious teachings, is a commendable attitude, not the other way around. On the other hand, though, there were still many students at SMP Negeri 2 Manado who did not have a commitment to implement the teachings of religious values in real lives, while Civic Education teachers did not follow it up in the teaching process; Characterization, students' attitudes to be faithful to their beliefs for it becomes their own character. It turns out that according to the students, they did not want to do things that were not good or not right, even though there were sanctions imposed by Civic Education teachers. However, some students disagreed with this point, so they were categorized as not wanting to obey and did not have a high religious character. Their lifestyle is often negligent, and their action is not based on religious values as they rarely worship and do not want to practice religious teachings in their daily life. There was a positive contribution from teachers who understood competence, where even though there were students who did not attend worship, but as teachers, they always advised and imposed sanctions. In addition to sanctions, researchers found about the assignments outside the school, and the data analysis showed that Civic Education teachers did not assign students to worship outside the school, that character-based learning could be designed both inside and outside the classroom [3]. Then, the teacher needs to design learning strategies and tips to be implemented during the learning and teaching process through the media as a strategic value assessment, which is also character education that serves in the affective aspect [6], and the same with indicators of religious values.

\section{CONCLUSION}

Based on the results and research discussion, there are several conclusions, as follows: (1) Internalization of religious values to students at SMP Negeri 2 Manado was carried out by Civic Education teachers in the learning process using a contextual rather than textual learning approach; (2) Internalization of religious values to students was carried out continuously by teachers who taught Civic Education at SMP Negeri 2 Manado, where after learning in class was continued by observing students' attitudes in real lives; (3) Internalization of values was carried out by Civic Education teachers by focusing on internalizing changing behavior, noble character, service attitudes, and internalizing of being able to prove and of being able to solve problems; (4) The aspect of internalizing religious values through Civic Education learning was still inadequate because it was the subject of religion teachers; (5) Internalization of religious values in Civic Education learning has not optimal because Civic Education teachers did not have control over students to attend worship at school and outside of school; (6) Civic Education teachers did not give sanctions to students who did not attend worship at school so that it made students to be ignorant to worship; (7) Students' disobedience in carrying out religious character values to be obedient to worship was because Civic Education teachers rarely gave students assignments to attend worship outside of school; (5) Religious values internalized by Civic Education teachers referred to the five levels of the affective aspect, as follows: (a) receiving; (b) responding; (c) valuing; (d) organizing; and (e) characterization.

\section{REFERENCES}

[1]. Hidayah, 2017.,Israfil 2012, Title of Skripsi: Internalisasi Nilai-Nilai PAI Metode Pembiasaan Pada Siswa SMP Muhammadiyah 8 Surakarta Tahun Pelajaran 2011/2012.

[2]. Kautsar A, Johan Edi, 2017, Pendidikan Karakter Religius, Disiplin dan Bakat Melalui peningkatan Sarana Prasarana Sekolah, Jurnal Manajemen, Kepemimpinan, dan Supervisi Pendidikan Volume 2, No. 2, Juli-Desember 2017

[3]. Dasim Budimansyah, 2018, Perancangan pembelajaran Berbasis Karakter, Edisi Revisi, Bandung: Widya Aksara Press

[4]. Kokom Komalasari, 2017, Pembelajaran Kontekstual, Konsep dan Aplikasi, Bandung: PT. Refika Aditama.

[5]. Marzuki Marzuki, Pratiwi Istifany Haq, 2018., Penanaman nilai karakter Religious dan Karakter Kebangsaan di Madrasah Tsanawiyah Al Falah Jatinagor Sumedang, Jurnal Pendidikan Karakter by Institute of Research and Community $\underline{\text { Service (LPPM - UNY) is licensed under a Creative }}$ Commons Attribution-ShareAlike 4.0 International License. Based on a work at http://journal.uny.ac.id/index.php/jpka.

[6]. Nasin Elkabumaini \& Rahmat Mulyana, 2016., Panduan Implementasi Pendidikan Budi Pekerti Untuk SD,SMP, dan SMA., Bandung: Yrama Widya. 